\title{
OBSERVATIONS ON LEAF DECURRENCY AND STEM WINGING IN SAUSSUREA ALPINA (L.) DC. SUBSP. MACROPHYLLA (SAUTER) NYMAN POPULATIONS FROM THE FĂGĂRAŞ MOUNTAINS
}

\author{
Gabriel LAZ $\breve{A R} \boldsymbol{R}^{I}$, Marius DANCIU ${ }^{2}$ \\ ${ }^{1}$ National Forestry Research and Development Institute "Marin Drăcea” - Braşov Branch, \\ 13 Cloşca Street, RO-500040, Braşov, Romania \\ ${ }^{2} 48$ Griviţei Street, ap. 29, RO-500182, Braşov, Romania \\ e-mail: gabi_e_1@yahoo.com
}

\begin{abstract}
Saussurea alpina (L.) DC. is a species with a large circumpolar Arctic-Alpine distribution range, recognized as highly polymorphic, due to variation in environmental factors but also possibly as a result of episodes of hybridization or manifestations of polyploidy. In the Făgăraş Mountains, on Buteanu Ridge, a population of Saussurea alpina subsp. macrophylla (Sauter) Nyman showing a significant percentage of individuals with winged stems due to leaf decurrency was discovered. Degree of decurrency ranged from low to high. This character, resulting in a winged stem, common to other species of the genus such as Saussurea porcii Degen and Saussurea parviflora (Poiret) DC, has not been reported so far in Saussurea alpina (L.) DC. Further research revealed the presence of winged stems also in other populations of Saussurea alpina from the Făgăraş Mountains.
\end{abstract}

Keywords: Saussurea alpina (L.) DC., leaf decurrency, winged stems, populations, Făgăraş Mountains.

\section{Introduction}

The genus Saussurea sensu lato is a large one, comprising over 400 species [9], with an extensive distribution, that has a genetic centre in Asia, but is also encountered in Europe ( 9 species), North America (6 species) and northern Australia (one species). The genus is divided into 6 subgenera and 20 sections. Among the subgenera, best represented is subgenus Saussurea, with groups in 10 sections and over 300 species [9]. The subgenus Saussurea, section Saussurea, which comprises 149 species, includes also the species Saussurea alpina (L.) DC. [9].

Saussurea alpina (L.) DC. has a large global distribution area, starting in Siberia and extending west to Northern and Central Europe [8]. It is generally a mountain species, specific to subalpine and alpine zones, reported at altitudes of up to $3000 \mathrm{~m}$, but in the northern part of the distribution area descends to the coastal regions [8]. In Romania the species has been reported in the following massifs: Rodnei, Hăşmaş, Bucegi, Făgăraş, Căpăţânii, Parâng and Ţarcu [11].

The main morphological characteristics of S. alpina are as follows [8, 11]:

- rhizomatous herbaceous perennial;

- stems solitary, erect, $10-70 \mathrm{~cm}$ in height, unwinged, terete, branched to the top, more or less pubescent;

- basal and lower stem leaves with petioles $1-4 \mathrm{~cm}$ long and sometimes narrowly winged. Leaves ovate-elliptic to linear-lanceolate, generally 5-12 x 0.7-3 cm, white-grey or grey-green pubescent beneath, green and hairless on the upper surface, the base of the blade rounded to 
cuneate-attenuate, with the margins almost entire to denticulate, the apex acute or acuminate. Upper leaves sessile, linear to lanceolate, $1-5 \mathrm{~cm} \times 0.1-1 \mathrm{~cm}$, decreasing in size towards the top of the stem, the base slightly amplexicaul, the margins smooth and the apex acuminate;

- inflorescence corymbiform or paniculiform, with 3-15 shortly pedunculate capitula, ovoid-cylindrical, $1.5-2 \mathrm{~cm}$ long and $0.7-1 \mathrm{~cm}$ in diameter. Phyllaries arranged in $4-5$ rows, without apical appendices, partially overlapping, greenish or reddish, glabrescent to pubescent, 3-9 mm long, ovate-elliptical or oblong, the apex acute to almost obtuse. Florets 10-20, tubular, the corolla blue to reddish-purple, $1-1.2 \mathrm{~cm}$ long, the tube 4-6 mm long and lobes 6-8 $\mathrm{mm}$ long;

- fruits, cylindrical achenes 2-3 mm long, light brown. Pappus brown at base and white to the top, with external bristles 1-3 mm long and internal ones 7-9 $\mathrm{mm}$.

In general the chromosome number of $S$. alpina is 26,52 or 54 , but it can also be 36,48 , 72 or $76[10]$.

The other 8 species of Saussurea encountered in Europe differ from S. alpina in the following main features [8]:

- phyllaries with a membranous appendage at the apex - S. amara (L.) DC.;

- solitary capitula - S. pygmaea (Jacq.) Sprengel;

- pinnatisect lower leaves - S. salsa (Pallas) Sprengel and S. turgaiensis B. Fedtsch.;

- winged stems - S. parviflora (Poiret) DC. and S. porcii Degen;

- leaves whitish-pubescent beneath, the lower triangular-ovate to triangular-lanceolate, with the base broadly truncate or cordate $-S$. discolor (Willd.) DC. and S. controversa DC.

Saussurea alpina (L.) DC. is characterized by being a highly polymorphic species, with great variability, especially: stem length, leaf shape, size, pubescence and margin, inflorescence type and pilosity of the phyllaries. The plant's polymorphism is determined both by variation of environment and result of some hybridization, in Western Europe probably with $S$. discolor (Willd.) DC. [8].

At a European level the following subspecies are recognized [8]:

- subsp. depressa (Gren.) Nyman - with procumbent and stems shorter than $10 \mathrm{~cm}$;

- subsp. esthonica (Baer ex Rupr.) Kupffer - with glabrous or subglabrous leaves and paniculate inflorescence;

- subsp. alpina - with lower leaves cuneate at the base (see Photo. 1);

- subsp. macrophylla (Sauter) Nyman - with lower leaves rounded or inconspicuously cordate at the base.

Although this variability has been known for a long time and studied in detail, the existence of Saussurea alpina plants with winged stems due to decurrent leaves has not yet been mentioned. Identification in the Făgăraş Mountains, on Buteanu Ridge, of a quite numerous population of S. alpina subsp. macrophylla (Sauter) Nyman with many plants having stems winged to various degrees, from pronouncedly broadly winged (see Photo. 2) to less winged, also alongside plants with cylindrical internodes (lacking decurrent leaves), allows for new taxonomic considerations and floragenetic assumptions, knowing that in Europe stem winging was considered characteristic only for Saussurea porcii Degen and S. parviflora (Poiret) DC. 


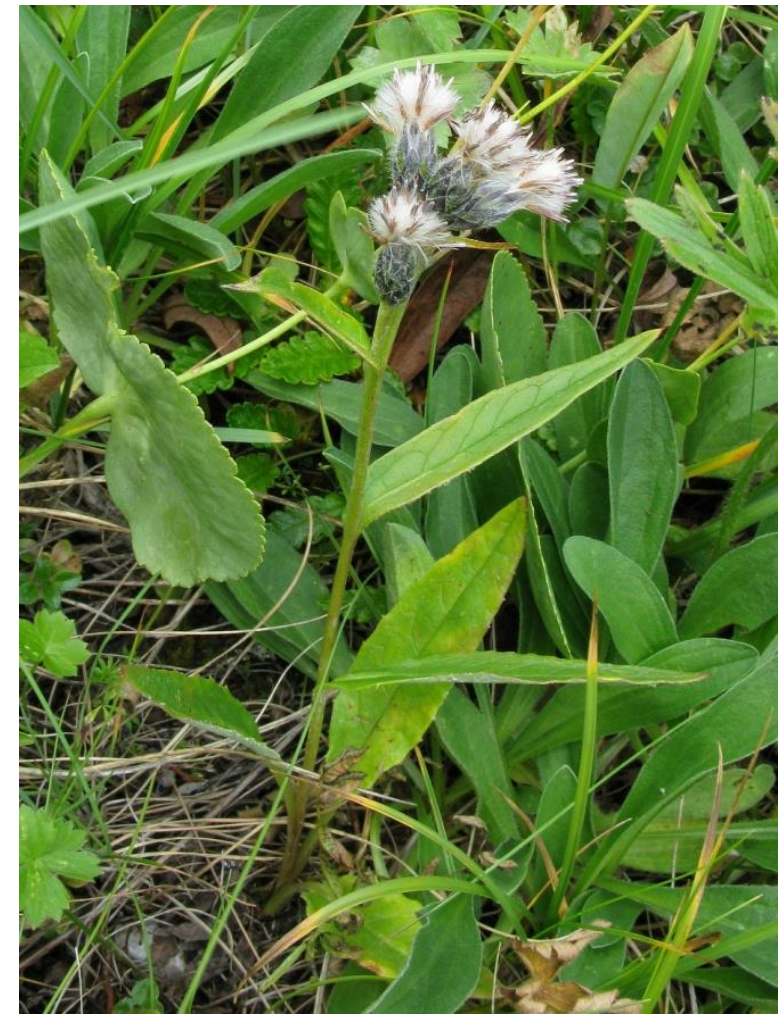

Photo 1: Saussurea alpina subsp. alpina, unwinged (G. Lazăr)

\section{Material and Methods}

The following observations were made:

1) the main site conditions were described;

2) an inventory of all cormophyte species from the area with S. alpina on Buteanu Ridge was carried out;

3) 3 categories of individuals, depending on the degree of stem winging were defined:

- individuals with broadly winged stems;

- individuals with narrowly or incompletely winged stems;

- individuals with unwinged stems (without decurrent leaves);

4) each of the fertile individuals of Saussurea alpina population from Buteanu Ridge was analyzed for stem winging, and the percentage of plants from each category was calculated;

5) observations on the existence of plants with winged stems in other populations of Saussurea alpina from the Făgăraş Mountains.

\section{Results}

The population of Saussurea alpina (L.) DC. subsp. macrophylla (Sauter) Nyman from the Buteanu Ridge is located at 2200-2300 m altitude, on a slope of western aspect, steep gradient $\left(50-80^{\circ}\right)$ and cliffs covering about $10 \%$ of the surface area. Soil is of humic umbrisoil type and was formed over crystalline shale bedrock. Vegetation conditions are not too limiting, a remarkable floristic diversity being present. The aspect and gradient of the slope determine a warmer microclimate, favorable for some of the species otherwise found mainly in alpine and subalpine meadows of limestone rocks. 
The plant community is represented by a phytocoenosis belonging to the association Seslerio bielzii - Caricetum sempervirentis Puşcaru et al. 1956 from alliance Festuco saxatilis Seslerion bielzii (Pawl. et Walas 1945) Coldea 1984, order Seslerietalia albicantis Br. - Bl. 1926, class Seslerietea albicantis Br.-B1. 1948 em. Oberdorfer 1978. South-East Carpathians communities of this association are found mainly on limestone, at lower altitudes (1650-2200 m) and of less sunny aspect, northern and north-eastern $[4,5]$. The western slope and higher altitude from Buteanu Ridge offer, by compensation, conditions similar to those that this type of phytocenosis finds at lower altitudes, on shaded aspects.

In the area with Saussurea alpina subsp. macrophylla, 54 cormophyte species were identified. Together with Sesleria bielzii - the characteristic species, and Carex sempervirens the species that largely determines the coenotic environment, other species are encountered as well, species that usually grow in meadows of Festuco saxatilis-Seslerion bielzii alliance: Festuca rupestris subsp. saxatilis, Scabiosa lucida subsp. barbata, Myosotis alpestris, Pedicularis verticillata, Trisetum fuscum, Anemone narcissiflora, Bartsia alpina subsp. carpatica, Hedysarum hedysaroides and Senecio integrifolius subsp. capitatus.

The characteristics of substrate and soil are reflected in the phytocoenosis composition by a large number of species that exhibit preferences for alpine acidophilous meadows from class Caricetea curvulae Br.-Bl. 1948, of oligotrophic soil on siliceous rocks: Juncus trifidus, Hieracium alpinum, Gnaphalium supinum, Campanula alpina, Vaccinium gaultherioides, Euphrasia minima, Thymus balcanus, Pulsatilla alba, Potentilla aurea subsp. chrysantha, Agrostis rupestris, Ranunculus pseudomontanus and Primula minima. It has been pointed out that the association Seslerio bielzii-Caricetum sempervirentis also includes an ecological variant that makes the transition to class Caricetea curvulae meadows, differentiated by species of alpine meadows on siliceous rocks. Moreover, the presence of the association on humic umbrisoils has been previously recorded from the Southern Carpathians [2, 3, 6].

High altitude conditions also favoured participation in the analyzed coenosis of some species found mainly in class Carici rupestris - Kobresietea bellardi Ohba 1974 grasslands, of high ridges with moderate declivity, where the snow melts earlier: Saussurea alpina subsp. macrophylla, Silene acaulis subsp. bryoides, Dryas octopetala, Carex atrata, Cerastium alpinum subsp. lanatum, Ligusticum mutellinoides, Achillea schurii, Trifolium repens subsp. ochranthum, Polygonum viviparum and Silene dinarica.

Atmospheric and soil humidity is reflected in the phytocoenosis composition by species characteristic for hydrophilic tall herb noda ("megaphorbiais") of nutrient-rich soils: Salix hastata, Aconitum tauricum, Polygonum bistorta, Polygonum alpinum, Viola biflora, Swertia perennis subsp. punctata and Cortusa matthioli. Generally these species have here a low vitality.

Some elements typical for screes were recorded as well: Doronicum carpaticum, Silene vulgaris, Luzula alpinopilosa subsp. obscura and Veronica baumgartenii.

Other species: Coeloglossum viride, Campanula serrata, Geum montanum, Silene pusilla, Huperzia selago, Soldanella hungarica, Saxifraga paniculata, Anthemis carpatica, Rhodiola rosea and Poa nemoralis var. montana.

The other two populations of Saussurea alpina studied in the Făgăraş Mountains, one from near Bâlea Lake (located about $1 \mathrm{~km}$ west from Buteanu Ridge) and one from "Fereastra Mare a Sâmbetei" (located about 18 km east from Buteanu Ridge), occur in vegetation with similar site and coenotic conditions. 
In the Saussurea alpina subsp. macrophylla population from Buteanu Ridge, 51 individuals with flowering stems were identified, of which $9(18 \%)$ had broadly winged stems, 25 (49\%) had narrowly winged stems (complete or incomplete) and 17 individuals (33\%) had unwinged stems (Fig. 1). The biological significance of this character can be inferred from observation that winging is more common in the upper leaves. In this way individuals with winged stems have a larger assimilation surface, a possible advantage in competition with neighbouring plant species, especially the competitive Cyperaceae and grasses. Also, it was observed that plants with broadly winged stems can grow taller and can produce more capitula, and therefore seeds, than plants with unwinged stems.

Also in the Făgăraş Mountains, in another quite numerous population of Saussurea alpina near Bâlea Lake, quite a few plants with broad (see Photo. 3) or narrow/incomplete wings were observed. In a third population studied, less numerous than those mentioned above, located in Sâmbetei "Great Window", plants with various degrees of stem winging, but less frequent, were identified. Therefore, it is possible that such populations, including individuals with stems more or less winged, may be numerous in the Făgăraş Mountains.

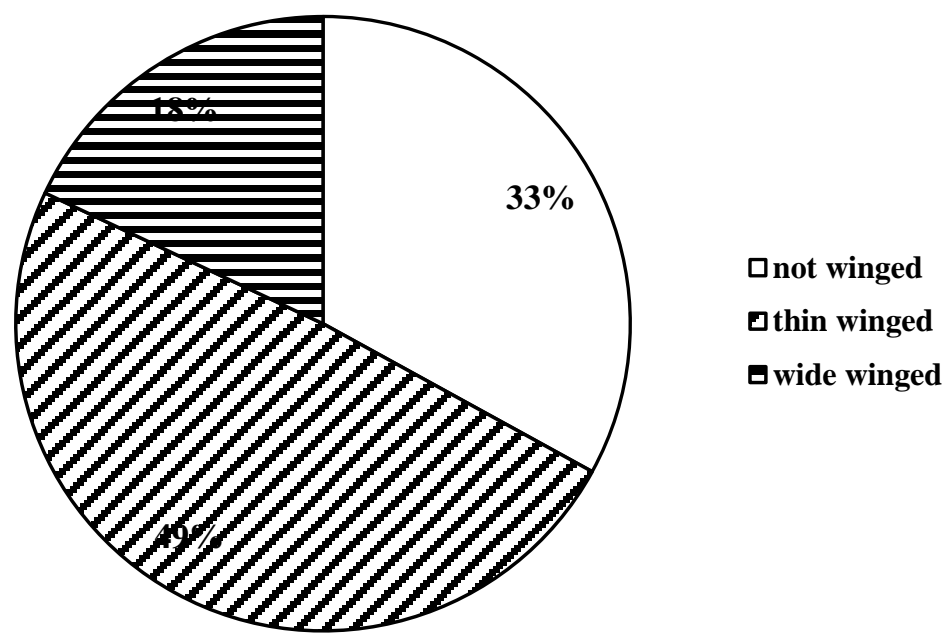

Fig. 1: The proportion of individuals (from Buteanu Ridge) according to the degree of stem winging

\section{Discussion}

It is known that through the great plant migrations during the last glaciation (Würm), when due to glaciers alpine species moved down and might have come into contact with Northern species which had moved south, a "certain uniformity of characters" occurred [1]. During the warming after the Würmian period, some species of alpine origin retreated northward, and some species of northern origin to the mountain tops. Therefore it is possible that during the last glaciation Saussurea alpina came into contact with $S$. porcii, or with S. parviflora. In this way it was possible to have gene-flow, which may be an explanation for the presence of stem winging in some populations of Saussurea alpina from the South-East Carpathians. Furthermore, the restrictive biotope conditions characteristic for the northern slopes of the Făgăraş Mountains favoured a larger-scale manifestation of this character. As a result, the stem winging (generally a feature of some Saussurea species with taller stems and from lower altitudes, where winging is mainly intended to strengthen the stem), in Saussurea alpina is a clear adaptation for increasing the assimilation surface. 


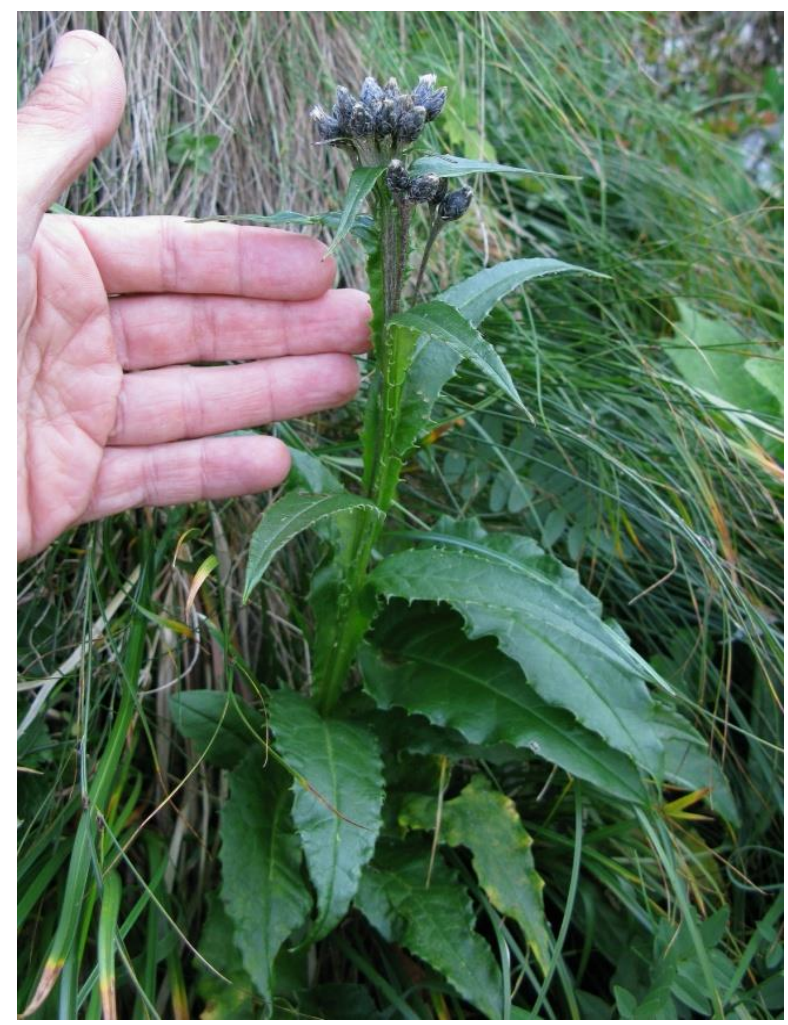

Photo 3: Saussurea alpina subsp. macrophylla, broadly winged, near Bâlea Lake (G. Lazăr)

A second hypothesis that can be considered is that stem winging, by decurrent leaves, is a character from the ancestral gene-pool of the species, probably induced by recessive genes and which generally was lost in time, but has acquired new expression, perhaps against a background of polyploidy, in the South-East Carpathians, recognized as a secondary centre of diversity for some species of Asian origin, such as Ligularia sibirica (L.) Cass. s. 1. and Cortusa matthioli L. s. 1. [7]. One may also cite the observation recorded on a plant of Saussurea alpina from Sweden, found within Herbarium of the Faculty of Silviculture and Forest Engineering at Braşov, which exhibits very narrow stem winging along the whole internode.

\section{Conclusions}

The discovery of this new morphological feature, namely stem winging, strengthens the well-known spectrum of polymorphism and adaptability of $S$. alpina species. At the same time it reduces the clear taxonomic pattern which at present differentiates this species, within the genus Saussurea, from the group of species with winged stems, as the percentage of individuals with this feature is significant, at least in some populations from the Făgăraş Mountains. At the same time, the South-East Carpathian region is reconfirmed as a secondary centre of diversity for some plant species of Asian origin.

Acknowledgements: We thank to our friends Tudor Stăncioiu, Adrian Indreica and Bogdan Candrea for help with the fieldwork and in writing this article. 


\section{REFERENCES}

1. Bănărescu, P., Boş̧caiu, N., 1973, Biogeografie. Perspectivă genetică şi istorică, Ed. Ştiinţifică, Bucureşti.

2. Boşcaiu, N., 1971, Flora şsi vegetaţia Munţilor Ţarcu, Godeanu şsi Cernei, Ed. Acad. Rom., Bucureşti.

3. Beldie, Al., 1967, Flora şi vegetaţia Munţilor Bucegi, Ed. Acad. Rom., Bucureşti.

4. Coldea, Gh., 1991, Prodrome des associations végétales des Carpates du Sud - Est (Carpates Roumaines), Documents Phytosociologiques, N.S., XIII: 317 - 539.

5. Coldea, Gh., Sanda, V., Popescu, A., Ştefan, N., 1997, Les associations végétales de Roumanie. Tome I: Les associations herbacées naturelles, Edit. Presa Universitară Clujeană, Cluj.

6. Puşcaru, D., Puşcaru-Soroceanu, E., Păucă, A., Şerbănescu, I., Beldie, Al., Ştefureac, Tr., Cernescu, N., Saghin, F., Creţu, V., Lupan, L., Tascenko, V., 1956, Păşunile alpine din Munţii Bucegi, Ed. Acad. Rom., Bucureşti.

7. Kobiv, Yu.Ya., Helesh, M,. Borsukevich, L.S., 2007, Saussurea porcii Degen (Asteraceae) in the Svydovets Mountains (Ukrainian Carpathians): location, cenotic conditions, population parameters and conservation, Ukr. Botan. Jurnal, m. 64, nr. 6: 825 - 832.

8. Lipschitz, S.J., 1994, Saussurea DC. In: Tutin, T.G. et al. (ed.), Flora Europaea, vol. 4, pp. 216 - 217. Cambridge University Press.

9. Lipšic, S.U., 1979, Rod Saussurea DC. (Asteraceae), Ed. „Nauka”, Leningrad.

10. Narits, A., Leht, M., Paal, L., 2000, Taxonomic status of Saussurea alpina subsp. esthonica (Asteraceae): phenetical analysis, Ann. Bot. Fennici, vol. 37: 197 - 206.

11. Nyárády, E.I., 1964, Saussurea DC. In: Săvulescu Tr. (ed.), Flora R.P.R., vol. IX, pp. 751 - 758. Ed. Acad. R.P.R., București.

12. Degen, A.v., 1904, Bewerkungen über einige orientalische Pflantzenarten, Magyar Botánikai lapok, III: 311 320.

13. Pawlowski, B., Walas, J., 1948, Les asociations des plantes vasculaires des Monts de Czywczyn, Bull. Acad. Pol. Scient. et Letter. - Ser. B. - V. 1: 117 - 181.

\section{OBSERVATTII ASUPRA DECURENTTEI FRUNZELOR ŞI ARIPĂRII TULPINII LA POPULAȚII DE SAUSSUREA ALPINA (L.) DC. SSP. MACROPHYLLA (SAUTER) NYMAN DIN MUNŢII FĂGĂRAŞ}

\section{(Rezumat)}

Saussurea alpina (L.) DC. este o plantă cu areal larg, circumpolar arctic - alpin, recunoscută ca fiind extrem de polimorfică în privinţa caracterelor morfologice, polimorfism determinat în primul rând de variaţia factorilor de mediu dar posibil şi ca urmare a anumitor hibridări sau manifestări ale fenomenului de poliploidie. În Munţii Făgăraş, pe culmea Buteanu, a fost descoperită o populaţie de Saussurea alpina subsp. macrophylla (Sauter) Nyman care prezintă un procent semnificativ de exemplare cu tulpini aripate prin decurenţa frunzelor, ariparea fiind de diferite grade, de la pronunţată la slabă. Acest caracter, ariparea tulpinii, comun altor specii din gen, precum Saussurea porcii Degen şi Saussurea parviflora (Poiret) DC, nu a mai fost semnalat până în prezent la Saussurea alpina (L.) DC. Cercetări ulterioare au evidenţiat prezenţa aripării tulpinii şi la alte populaţii de Saussurea alpina din Munţii Făgăraş. 